\title{
PENGEMBANGAN LKPD ELEKTRONIK PEMBELAJARAN TEMATIK BERBASIS HIGH ORDER THINKING SKILL (HOTS)
}

\author{
Sri Rahayu ${ }^{1}$, Iskandar Ladamay ${ }^{2}$, Nurul Ulfatin ${ }^{3}$, Farida Nur Kumala ${ }^{4}$, Siti Aminatun \\ Watora $^{5}$ \\ 1,2, 4, 5 Universitas PGRI Kanjuruhan Malang \\ ${ }^{3}$ Universitas Negeri Malang
}

\begin{abstract}
The purpose of this study was to develop teaching materials Electronic LKPD Thematic Learning Based on High Order Thinking Skill (HOTS) for High Grade Students and test the feasibility, practicality and attractiveness of Electronic LKPD. The research applied development method by using 4D model that had four stages: definition stage, design stage, development stage, and dissemination stage. Instruments in this research were questionnaires and documentation. The questionnaire consists of material experts, media experts, linguists, practitioners (teachers) and student response questionnaires. Data analysis technique used quantitative and qualitative descriptive. The result of this research was Electronic LKPD obtained score of $83.4 \%$ with an interesting category. Based on the exposure of assessment results above, Electronic LKPD teaching materials categorized as Very Appropriate and Very Good for use. The results of development Electronic LKPD teaching materials could be used as references as companion teaching materials during teaching and learning activities.
\end{abstract}

Keyword: Electronic LKPD, Thematic, HOTS

\begin{abstract}
Abstrak: Tujuan dari penelitian ini adalah untuk mengembangkan bahan ajar LKPD Elektronik Pembelajaran Tematik Berbasis High Order Thinking Skill (HOTS) untuk Siswa Kelas Tinggi dan menguji kelayakan, kepraktisan dan kemenarikan bahan ajar LKPD Elektronik tersebut. Metode penelitian yang digunakan yaitu penelitian pengembangan dengan menggunakan model 4D dengan empat tahapan yaitu: tahap pendefinisian (Define), tahap perancangan (Design), tahap pengembangan (Development), tahap penyebaran (Disseminate). Instrumen yang digunakan dalam penelitian ini yaitu angket dan dokumentasi. Angket tediri dari ahli materi, ahli media, ahli bahasa, praktisi (guru) dan angket respon siswa. Teknik analisis data menggunakan deskriptif kuantitatif dan kualitatif. Hasil penelitian ini adalah LKPD Elektronik memperoleh skor 83,4\% dengan kategori menarik. Berdasarkan paparan dari hasil penilaian diatas bahan ajar LKPD Elektronik dikategorikan Sangat Layak dan Sangat Baik digunakan di lapangan. Hasil pengembangan bahan ajar LKPD Elektronik dapat dijadikan referensi sebagai bahan ajar pendamping pada saat kegiatan belajar mengajar.
\end{abstract}

Kata Kunci: LKPD Elektronik, Tematik, HOTS

\footnotetext{
'Universitas PGRI Kanjuruhan Malang, Email: srisk国unikama.ac.id

2Universitas PGRI Kanjuruhan Malang, Email: ladamay国unikama.ac.id

${ }^{3}$ Universitas Negeri Malang, Email: nurul.ulfatin.fip国um.ac.id

${ }^{4}$ Universitas PGRI Kanjuruhan Malang, Email: faridankumalalanikama.ac.id

[Universitas PGRI Kanjuruhan Malang, Email: watarasitiaminatun国gmail.com
} 


\section{PENDAHULUAN}

Pelaksanaan Kurikulum 2013 untuk SD/MI dikembangkan dengan mengunakan pendekatan tematik terpadu yang memungkinkan siswa baik secara individu maupun kelompok aktif menggali dan menemukan konsep serta prinsip-prinsip keilmuan secara holistik, bermakna, dan otentik (Majid, 2014). Salah satu cara mengimplementasikan pendekatan tematik di dalam kelas yaitu dengan mengemas materi pembelajaran dalam bentuk Lembar Kerja Peserta Didik (LKPD). LKPD merupakan salah satu bahan ajar yang berperan penting dalam memberikan penugasan yang relevan dengan materi yang diajarkan, belajar akan lebih mudah jika disertai dengan sumber belajar berupa LKPD yang dirancang secara khusus. Selain itu juga LKPD sebagai sarana pendukung dalam mencapai kompetensi peserta didik dalam bernalar dengan mudah. Menurut (Choo et al., 2011) LKPD adalah alat intruksional yang terdiri dari serangkaian pertanyaan dan informasi yang dirancang untuk membimbing peserta didik untuk memahami ide-ide yang kompleks karena mereka bekerja secara sistematis. LKPD membantu siswa dalam memahami materi di berbagai level pendidikan (Bakri et al., 2020; Muskita et al., 2020; Sagita et al., 2018).

Kegiatan belajar mengajar yang hanya memanfaatkan bahan ajar seadanya seperti buku pegangan guru dan siswa, dapat mengakibatkan pembelajaran kurang menarik bagi siswa (Sukardi et al., 2021, 2017). Dibutuhkan bahan ajar yang menarik dan inovatif bagi kemajuan mutu pendidikan. Salah satu cara untuk meningkatkan antusias siswa dan menciptakan suasana yang menyenangkan dalam proses pembelajaran yaitu dengan menggunakan lembar kerja peserta didik yang memanfaatkan teknologi.

Berdasarkan hasil observasi di sekolah, pengunaan LKPD belum mampu memotivasi siswa dalam proses pembelajaran (Yurtyapan \& KandemiR, 2021). Hal ini dikarenakan LKPD yang digunakan kurang menarik, kurang efektif dan dianggap belum maksimal, hal ini menyebabkan siswa kurang termotivasi menggunakan LKPD yang sudah tersedia. Penelitian yang dilakukan oleh (Subekti \& Suparman, 2019) mengatakan bahwa bahan ajar yang digunakan oleh guru masih memiliki banyak kelemahan. Seiring berkembangnya zaman, maka media pembelajaran juga telah berubah dari konvensional menjadi digital, tidak terkecuali LKPD. Penggunaan media pembelajaran secara elektronik telah lama menjaid pilihan dalam Pendidikan (Bakri et al., 2020). Oleh sebab itu guru perlu melakukan pengembangan bahan ajar yang memanfaatkan teknologi seperti Lembar Kerja Peserta Didik Elektronik (E-LKPD). E-LKPD ini mampu membangun pengetahuan konseptual siswa apabila dipandu oleh guru yang mampu menghadirkan kegiatan pembelajaran yang mengoptimalkan hands-on dan minds on (Sopandi et al., 2019).

Guru-guru perlu melakukan mengembangkan bahan ajar karena pengembangan terhadap bahan ajar dapat memberikan manfaat pada peningkatan kemampuan guru juga dapat meningkatkan hasil belajar siswa dan keterampilan siswa. Bahan ajar yang dikembangkan guru harus sesuai dengan tuntunan Kurikulum 2013 yaitu dapat meningkatkan kemampuan siswa dalam berpikir tingkat tinggi HOTS (High Order Thingking Skills). Kemampuan berpikir tingkat tinggi atau HOTS merupakan kemampuan yang harus ada dalam diri setiap peserta didik (Darmawan \& Wahyudin, 2018). Hasil penelitian terdahulu menunjukan bahwa LKPD yang dibuat oleh guru jarang yang mengembangkan HOTS siswa (Bakri et al., 2020).

Menyadari bahwa HOTS perlu dilatihkan pada siswa maka dibutuhkan LKPD elektronik karena selama ini ketersediannya masih belum banyak sehingga penelitian ini bertujuan untuk mengembangkan LKPD Elektronik Berbasis High Order Thingking Skills 
(HOTS) Untuk Siswa Kelas IV Tema Daerah Tempat Tinggalku Subtema Bangga Terhadap Derah Tempat Tinggalaku Pembelajaran 1 di SDN Tanjungrejo 04 Kota Malang”.

\section{METODOLOGI PENELITIAN}

Penelitian ini menggunakan jenis penelitian pengembangan Reaearch and Development (R\&D). Model penelitan pengembangan yang digunakan oleh peneliti adalah model 4D terdiri dari empat tahap biasanya dikenal dengan model Thiagrajan (Sari, 2017). Empat tahap tersebut yaitu: 1) tahap pendefinisian (define), 2) tahap perencanaan (design), 3) tahap pengembangan (development), 4) tahap penyebaran (dissemninate). Namun peneliti akan menggunkan model 4D sampai dengan tahap pengembangan karena pada tahap penyebaran peneliti tidak memperbanyak produk dengan skala yang lebih luas.

Subjek yang digunakan dalam penelitian ini adalah siswa kelas IV SDN Tanjungrejo 04 Kota Malang yang berjumlah 10 siswa. Penelitian pengembangan bahan ajar LKPD Elektronik dilakukan di SDN Tanjungrejo 04 Kota Malang.

Instrumen pengumpulan data dalam penelitian LKPD Elektronik menggunakan Lembar Kuesioner/ Angket, dan catatan lapangan serta dokumentasi. Prosedur pengumpulan data bertujuan untuk mendapatkan data yang digunakan sebagai dasar untuk melakukan perbaikan dalam rangka mencapai tingkat kevalidan, kepraktisan, dan kemenarikan LKPD Elektronik. Hasil pengembangan subjek uji coba dipilih secara acak, untuk menentukan peserta didik yang berkemampuan tinggi, sedang dan rendah.

Teknik analisis data yang digunakan pada penelitian pengembangan ini yaitu analisis data kuantitatif dan kualitatif. Analisis data kevalidan LKPD Elektronik yang diperoleh dari Dosen-Dosen Pendidikan Guru Sekolah Dasar (PGSD) Universitas Kanjuruhan Malang, dengan krieria minimal telah menyelesaikan S2. Validator ahli pembelajaran yaitu dosen pakar pembelajaran serta praktsi yaitu gur kelas dengan kriteria minimal telah menyelesaikan S1.

\section{HASIL PENELITIAN DAN PEMBAHASAN}

Penelitian pengembangan ini menghasilkan LKPD Elektronik Berbasis High Order Thingking Skills (HOTS) Untuk Siswa Kelas IV menggunakan aplikasi Kvisoft Flip Book Maker. Komponen LKPD Elektronik ini terdiri dari:

1. Pendahuluan terdiri dari:
a. Kompetensi Inti
b. Komptensi Dasar
c. Indikator
d. Tujuan

2. Isi

Isi pada LKPD Elektronik berisi tentang materi, ringkasan materi dan soalsoal latihan/evaluasi yang berbasis High Order Thinking Skills (HOTS). Adapun soal yang dikembangkan sesuai dengan Taksonomi Bloom pada ranah $\mathrm{C} 4$ (Analisis), C5 (Evaluasi), dan C6 (Kreasi). 3. Penutup

Penutup pada LKPD Elektronik berisi rubrik penilaian guru, daftar pustaka dan profil penulis.

Adapun LKPD Elektronik Berbasis Berbasis High Order Thingking Skills (HOTS) Untuk Siswa Kelas IV menggunakan aplikasi Kvisoft Flip Book Maker dapat dilihat pada gambar di bawah ini.

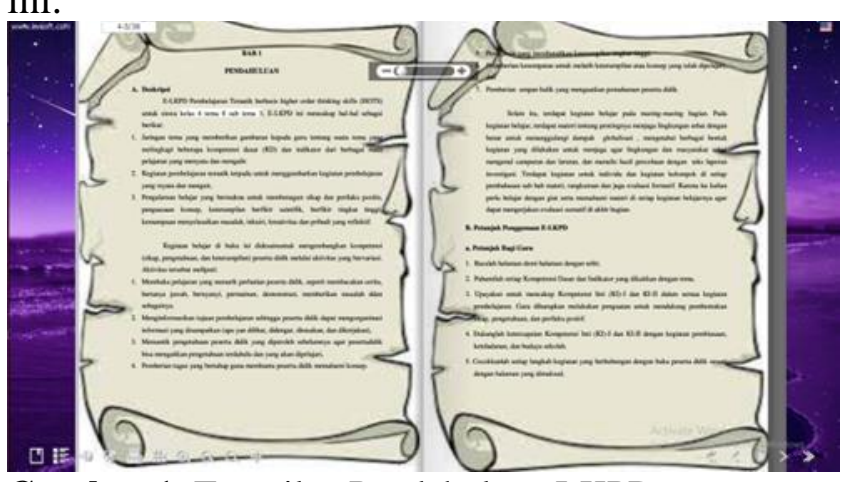

Gambar 1. Tampilan Pendahuluan LKPD Elektronik Menggunakan Software Kvisoft Flip Book Maker 


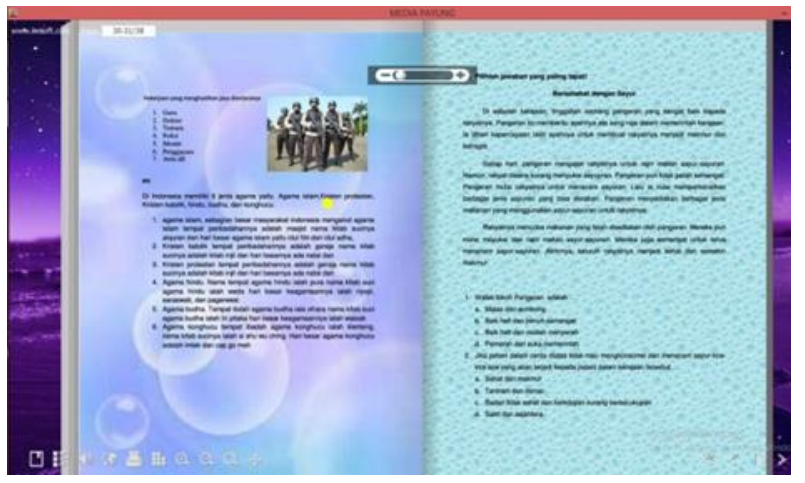

Gambar 2. Tampilan Isi LKPD Elektronik menggunakan Software Kvisoft Flip Book Maker

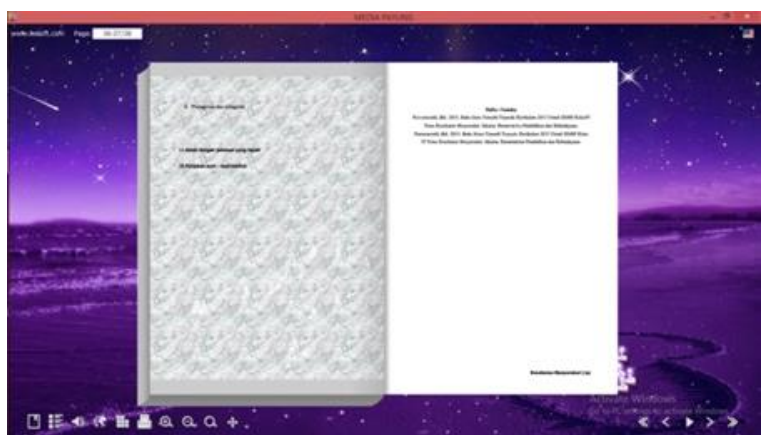

Gambar 3. Tampilan Penutup LKPD Elektronik menggunakan Software Kvisoft Flip Book Maker

LKPD Elektronik berbasis High Order Thingking Skills (HOTS) Untuk Siswa Kelas IV Tema Daerah Tempat Tinggalku Subtema Bangga Terhadap Daerah Tempat Tinggalku Pembelajaran 1 yang telah berhasil dikembangkan kemudian diuji kevalidannya kepada para validator ahli. Adapun hasil uji kevalidan LKPD Elektronik yang telah dikembangkan adalah sebagai berikut.

Hasil uji kevalidan oleh validator ahli media terhadap bahan ajar LKPD Elektronik secara keseluruhan diperoleh skor $90,6 \%$ yang artinya bahan ajar sangat valid. Dengan demikian dapat disimpulkan bahwa bahan ajar LKPD Elektronik ini valid untuk digunakan dikelas IV SDN Tanjungrejo 04.

Hasil uji kevalidan oleh validator ahli materi terhadap bahan ajar LKPD Elektronik secara keseluruhan diperoleh skor $96,4 \%$ yang berarti bahan ajar valid. Dengan demikian dapat disimpulkan bahwa materi yang terdapat dalam LKPD
Elektronik ini valid digunakan oleh siswa kelas IV SDN Tanjungrejo 04.

Hasil uji kevalidan oleh ahli bahasa terhadap kosakata atau kalimat yang terdapat dalam bahan ajar LKPD Elektronik secara keseluruhan memperoleh skor $85,4 \%$ yang berarti kosakata atau kalimat yang terdapat dalam LKPD Elektronik valid. Dengan demikian dapat disimpulkan bahwa baha ajar LKPD Elektronik ini valid digunakan siswa kelas IV SDN Tanjungrejo 04. Dalam penelitian ini, peneliti juga memberikan sebuah angket kepada 10 orang siswa sebagai subyek peneliti untuk mengetahui kemenarikan dari LKPD Elektronik dan wali kelas IV yang sudah mengetahui karakteristik setiap pesera didik. Hasil penilaian angket respon siswa tentang bahan ajar LKPD memperoleh tingkat kemenarikan sebesar $84,3 \%$ yang berarti bahan ajar LKPD Elektronik sangat menarik. Hasil penilaian angket respon guru sebagai ahli praktisi memperoleh skor sebesar 93,3\% dengan kategori praktis. Dengan demikian dapat disimpulkan bahwa LKPD Elektronik sangat menarik dan praktis digunakan oleh siswa kelas IV SDN Tanjungrejo 04 Kota Malang.

Hasil ini sesuai dengan hasil beberapa penelitian yang menyatakan bahwa bentuk media pembelajaran dalam bentuk digital atau paperless mudah dan menarik digunakan (Sagita et al., 2018; Yurtyapan \& KandemiR, 2021; Zhang \& Lin, 2020). LKPD Elektronik yang telah dikembangkan merupakan panduan kerja peserta didik untuk mempermudah peserta didik dalam pelaksanaa kegiatan pembelajaran dalam bentuk elektronik yang dapat dilihat pada desktop komputer, notebook, maupun smartphone. Bentuk LKPD seperti ini akan menjadi masa depan gaya hidup siswa.

LKPD Elektronik yang menarik haruslah didesain sesuai dengan kebutuhan peserta didik dan kondisi lingkungan di sekolah sesuai dengan kebutuhan pembelajaran saat ini. Hal ini tentu akan membuat proses pembelajaran berjalan 
lebih efektif dan lebih bermanfaat bagi peserta didik terutama dalam memfasilitasi kemampuan penalaran siswa sesuai dengan Kurikulum 2013, dimana peserta didik harus memiliki kecapakapan berfikir tinggat tinggi atau High Order Thinking Skills (HOTS).

High Order Thinking Skills (HOTS) atau keterampilan berpikir tingkat tinggi merupakan bagian dari Taksonomi Bloom yang terdiri dari analyse $(\mathrm{C} 4)$, evaluate (C5), dan create (C6) yang digunakan dalam penyusunan soal-soal LKPD Elektronik. Soal-soal High Order Thinking Skill (HOTS) bukanlah soal yang sulit, redaksinya panjang dan berbelit-belit sehingga tidak membuang waktu membacanya dan sistematis untuk mengukur Indikator Ketercapaian Kompetensi (IKK) secara efektif serta memiliki kedalaman materi sehingga siswapun terangsang untuk menjawab pertanyaan dengan baik (Elfeky, 2019; Yurdakul et al., 2020).

Pelaksanaan Kurikulum 2013 melalui pendekatan tematik terpadu menjadi alasan peneliti melakukan pengembangan bahan ajar LKPD Elektronik pada Pembelajaran Tematik. Pembelajaran tematik adalah pembelajaran terpadu yang menggunakan tema untuk mengaitkan beberapa mata pelajaran sehingga guru dapat memberikan pengalaman belajar kepada siswa.

Pembelajaran tematik akan menciptakan sebuah pembelajaran terpadu yang akan mendorong keterlibatan siswa dalam belajar, membuat siswa aktif dalam proses pembelajaran dan menciptakan suasana pemecahan masalah sesuai dengan kebutuhan siswa, dalam pembelajaran tematik siswa akan mampu belajar dan bermain dengan kreativitas yang tinggi. Pembelajaran tematik juga dapat diartikan sebagai pola pembelajaran yang mengintegrasikan pengetahuan, keterampilan, kemahiran, nilai dan sikap pembelajaran dengan menggunakan tema. Pembelajaran tematik sangat penting diintegrasikan bagi siswa SD/MI agar nantinya mereka dapat menjadi siswa yang mempunyai skill dalam sikap, pengetahuan dan keterampilan.

Bahan ajar LKPD Elektronik yang sudah dikembangkan oleh peneliti ini memiliki beberapa kelebihan dan kelemahan yaitu sebagai berikut. Kelebihan bahan ajar LKPD Elektronik yaitu desain LKPD Elektronik terdapat video animasi cerita pendek, cerita lagenda, gambar dan video tentang gaya dan gerak serta perpaduan warna-warna background yang tidak membuat anak menjadi bosan, bahasa yang digunakan sederhana dan mudah dipahami, pengaplikasianya dalam penggunaan LKPD Elektronik bisa digunakan secara individu maupun kelompok.

\section{KESIMPULAN}

Berdasarkan hasil penelitian dan pembahasan pengembangan LKPD Elektronik berbasis hots, maka dapat diambil kesimpulan sebagai berikut 1) LKPD Elektronik sangat valid digunakan, hal ini ditunjukan dari hasil validasi ahli media memperoleh skor 90,6\% dengan kategori sangat layak. Hasil penilaian kelayakan LKPD Elektronik oleh ahli materi memperoleh skor $96,4 \%$ dengan kategori sangat layak. Hasil penilaian kelayakan LKPD Elektronik oleh ahli bahasa memperoleh skor $85,4 \%$. 2) Bahan ajar LKPD Elektronik sangat praktis digunakan untuk kelas IV dengan mendapatkan skor sebesar 93,3\% dengan kategori Praktis. 3) LKPD Elektronik sangat menarik digunakann untuk kelas IV SDN Tanjungrejo 04 sangat menarik digunakan. Hal ini dapat dilihat dari hasil respon angket siswa dengan mendapatkan skor $84,3 \%$. Berdasarkan hasil penelitian pengembangan ini, bahan ajar LKPD Elektronik dapat digunakan oleh guru pada saat kegiatan belajar mengajar (KBM) sehingga dapat mempermudah guru untuk menyiapkan materi, serta dapat digunakan guru sebagai referensi dalam mengembangakan bahan ajar. Penelitian pengembangan bahan ajar LKPD Elektronik ini dapat digunakan peneliti 
untuk menambah pengetahuan dan juga keterampilan dalam merancang bahan ajar LKPD dan menjadi referensi bagi peneliti lain.

\section{DAFTAR PUSTAKA}

Bakri, F., Permana, H., Wulandari, S., \& Muliyati, D. (2020). Student worksheet with AR videos: Physics learning media in laboratory for senior high school students. Journal of Technology and Science Education, $\quad 10(2), \quad 231$. https://doi.org/10.3926/jotse.891

Choo, S. S. Y., Rotgans, J. I., Yew, E. H. J., \& Schmidt, H. G. (2011). Effect of Worksheet Scaffolds on Student Learning in Problem-Based Learning. Advances in Health Sciences Education, 16(4), 517528.

https://doi.org/10.1007/s10459011-9288-1

Darmawan, D., \& Wahyudin, D. (2018). Model Pembelajaran di Sekolah. PT Remaja Rosdakarya.

Elfeky, A. I. M. (2019). The effect of personal learning environments on participants' higher order thinking skills and satisfaction. Innovations in Education and Teaching International, 56(4), 505-516. https://doi.org/10.1080/14703297.2 018.1534601

Majid, A. (2014). Strategi Pembelajaran. PT Remaja Rosdakarya.

Muskita, M., Subali, B., \& Djukri, D. (2020). Effects of Worksheets Base the Levels of Inquiry in Improving Critical and Creative Thinking. International Journal of Instruction, 13(2), 519-532. https://doi.org/10.29333/iji.2020.13 $236 \mathrm{a}$

Sagita, L., Widagsa, R., \& Dwipa, N. M. S. (2018) DEVELOPING BILINGUAL SCIENTIFICWORKSHEET FOR INDEFINITE INTEGRAL. Journal on Mathematics Education, 9(2), 249-
258.

https://doi.org/10.22342/jme.9.2.54 $01.249-258$

Sari, S. A. (2017). The Development of Pop-up Book on the Role of Buffer in the Living Body. European Journal of Social Sciences Education and Research, 10(2), 1223.

https://doi.org/10.26417/ejser.v10i 2.p213-221

Sopandi, W., Sukyadi, D., \& Sukardi, R. R. (2019). The Implementation of Guided Research-Based Learning with Graduate School Students of an Elementary Education Study Program. Pedagogika, 134(2), 8298.

https://doi.org/10.15823/p.2019.13 4.5

Subekti, M. A. S., \& Suparman. (2019). Analisis kebutuhan E-LKPD untuk menstimulus kemampuan berpikir kritis dengan model pembelajaran discovery learning. Proceedings of the Steeem 2019, 1(1), 185-192.

Sukardi, R. R., Sopandi, W., \& Riandi. (2021). How do teachers develop secondary school students' creativity in the classroom? AIP Conference Proceedings, 2331(1), 030024. https://doi.org/10.1063/5.0042030

Sukardi, R. R., Widodo, A., \& Sopandi, W. (2017). Describing Teachers' Pedagogic Content Knowledge about Reasoning Development and Students' Reasoning Test. Proceedings of the 2016 International Conference on Mathematics and Science Education, 14-20. https://doi.org/10.2991/icmsed16.2017.4

Yurdakul, B., Başokçu, T. O., \& Yazıcılar, Ü. (2020). Evaluation of the Professional Development Program for Sec- ondary Math Teachers on Item Writing Related to Higher Order Thinking Skills. Journal of 
Teacher Education and Educators, 9(1), 83-106.

Yurtyapan, E., \& KandemiR, N. (2021).

The Effectiveness of Teaching with Worksheets Enriched with Concept Cartoons in Science Teaching Laboratory Applications.

Participatory Educational Research, 8(3), 62-87. https://doi.org/10.17275/per.21.54.

8.3

Zhang, Y., \& Lin, C.-H. (2020). Student interaction and the role of the teacher in a state virtual high school: What predicts online learning satisfaction? Technology, Pedagogy and Education, 29(1), 57-71. https://doi.org/10.1080/1475939X. 2019.1694061 